\title{
Concentração de Deoxinivalenol em Farinhas de Trigo
}

\author{
Leisiane Valbring (I), Alana Meira Reichert (II), Juliete Gomes de \\ Lara de Souza (II), Paula Andrade Sonsin (II) \\ (I) FAG - Faculdade Assis Gurgacz (Avenida das Torres, 500 - Loteamento FAG - Cascavel - \\ Paraná), (II) UNIOESTE - Universidade Estadual do Oeste do Paraná (Rua Universitária, 2069 - \\ Jardim Universitário - Cascavel - Paraná)
}

\section{Resumo}

A farinha de trigo possui inúmeras aplicações na indústria de alimentos, contudo, é imprescindível o controle em todo o processo de obtenção. Considerando a predominância de Fusarium graminearum no grão de trigo e a sua contaminação por deoxinivalenol (DON), foram analisadas 1391 amostras de farinha de trigo produzidas na região do oeste do Paraná no período de janeiro de 2012 a dezembro de 2013, com objetivo de avaliar a concentração minima e máxima da presente micotoxina, bem como a concentração média das amostras análisadas. Inicialmente, foi utilizado 10 g de cada amostra e realizou-se a diluição em água destilada 1:20 (10 g de amostra para $200 \mathrm{ml}$ de água), e posterior homogeneização e filtração para extração da micotoxina DON. Após, foi realizado o teste para detecção por meio do Kit Veratox DON HS e em seguida, a leitura dos resultados em um leitor de micropoços, o método ELISA (enzyme-linked immunosorbent assay). Os resultados são preconizados por meio do método de referência GC e aprovado pelo GIPSA/USDA, quantificados, multiplicando-se por 4 (transformando a diluição de 1:20 em 1:5) obtendo-se em ppb $(\mu \mathrm{g} / \mathrm{kg})$ os níveis de deoxinivalenol. As amostras analisadas em 2012 apresentaram concentração média de $591,8 \mu \mathrm{g} / \mathrm{kg}$, mínimo e máximo de $52,8 \mu \mathrm{g} / \mathrm{kg}$ e $5080 \mu \mathrm{g} / \mathrm{kg}$, respectivamente, no ano de 2013 apresentou média de 408,5 $\mu \mathrm{g} / \mathrm{kg}$, concentração máxima de $1491,6 \mu \mathrm{g} / \mathrm{kg}$ e mínima de $64 \mu \mathrm{g} / \mathrm{kg}$. Conclui-se que a farinha de trigo é um alimento muito susceptível a contaminação pela micotoxina DON, portanto deve-se ter um controle

\footnotetext{
Referência:

Leisiane Valbring, Alana Meira Reichert, Juliete Gomes de Lara de Souza, Paula Andrade Sonsin.Concentração de Deoxinivalenol em Farinhas de Trigo. In: Anais do $1^{\circ}$ Congresso Latinoamericano de Microbiologia e Higiene de Alimentos - MICROAL 2014 [= Blucher Food Science Proceedings, num.1, vol.1]. São Paulo: Editora Blucher, 2014.

DOI 10.5151/foodsci-microal-051
} 
rigoroso durante colheita e armazenamento do trigo, bem como no beneficiamento dos seus derivados tais como a farinha, para evitar danos causados pela micotoxina, a qual causa um grande dano à saúde tanto humana quanto animal. $\mathrm{O}$ armazenamento influencia muito na concentração de micotoxina, pois pode oferecer um ambiente propicio para a proliferação dos vetores, aumentando a quantidade de contaminação.

Palavras-Chave: Deoxinivalenol, Farinha de trigo, Micotoxina Agência de Fomento: 